\section{Bagged Soil Tested as an Alternative for Growing Bedding Plants in the Landscape}

\author{
Clydette M. Alsup ${ }^{1}$ and Pamela B. Trewatha \\ Missouri State University, 901 S. National Ave., Springfield, Missouri 65897
}

Additional index words. Raised beds, ornamentals, bag culture, topsoil, annuals, Alternanthera dentata, Capsicum annuum

\begin{abstract}
Many homeowners have difficulty establishing ornamental gardens in shallow, rocky soils. "Gardening in a Bag" (planting directly into bags of topsoil) offers a viable alternative for growing many herbaceous ornamental plants. This study compares the growth and appearance of several herbaceous bedding plants using "Gardening in a Bag" versus "in the ground" planting methods. Twenty-five cultivars of Alternanthera dentata R. Br., ornamental pepper (Capsicum annuum var. annuum L.), dianthus (Dianthus barbatus L.), gazania [Gazania rigens (L.) Gaertn.], marigold (Tagetes patula L.), petunia (Petunia hybrida hort. ex E. Vilm.), salvia (Salvia splendens Sellow ex Schult.), peek-a-boo plant (Spilanthes oleracea L.), verbena (Verbena hybrida hort. ex Groenl. \& Rümpler), and vinca [Catharanthus roseus (L.) G. Don] were evaluated in 2002 under the two planting methods: in the ground versus in bags of topsoil. Wave petunias, dianthus, vinca, and rose moss (Portulaca grandiflora Hook.) were evaluated using the same methods in 2003. All plants were mulched with $7.5 \mathrm{~cm}$ coarse sawdust. In 2002, the planting method had no effect on the average height for 16 of the 25 cultivars tested. Seven cultivars were taller when grown in the ground whereas two cultivars were shorter during that treatment. Planting method had no effect on average plant spread of 13 of the cultivars. Plant spread was greater for nine cultivars grown in bags, whereas three cultivars were wider when grown in the ground. Visual ratings of overall appearance were similar for 14 of the cultivars regardless of planting method. In 2003, performance of the five species was evaluated on 3 July, 29 July, and 5 Sept. Planting method did not affect growth and appearance of rose moss or vinca. The two petunia cultivars and the dianthus tended to be taller and wider and had more flowers when grown in the ground compared with growth in bags. Visual quality of the petunias and the dianthus was unaffected by planting method until September when the 'Purple Wave' petunias and the dianthus grown in the ground received better ratings than plants grown in bags.
\end{abstract}

Gardening is America's number one leisure activity (Relf, 1989), but rocky soils make it difficult for some homeowners to establish ornamental gardens. Homeowners in the Missouri Ozarks often use shovels, picks, or pry bars to create garden beds, but such activity is not possible for many persons, especially those who are elderly or handicapped. Alternatives to preparing a plot of soil for a garden include containers (Pinnell, 1990; Relf, 1989) or raised beds (Elliott, 1979; Finnis, 1973; Gray, 1991; Purser and Comeau, 1991; Relf, 1989; Walters, 1998). Container gardening works well for many people but has several drawbacks. The potting substrate in containers often dries out quickly, requiring frequent watering; and containers may restrict plant root growth, which can affect plant growth and performance (Keever et al., 1985; Menzel et al., 1994). Root zone temperatures can become abnormally high in containers (Reiger and Whitcomb, 1983), resulting in damage to root

Received for publication 19 Jan. 2006. Accepted for publication 23 Apr. 2006.

${ }^{1}$ To whom correspondence should be addressed; e-mail clydettealsup@missouristate.edu ers (Relf, 1989); however, these planting bags may be difficult to find (we did not find the bags at any area garden centers or in print or online catalogs). Only one report on outdoor bag culture for crops (Hochmuth et al., 1998) was found, but the study did not compare bag culture with ground culture. No reports were found of research focusing on the use of grow bags in landscape gardening. The current study evaluated whether "Gardening in a Bag" is a feasible method for growing outdoor herbaceous ornamentals.

\section{Materials and Methods}

\section{2}

Seeds of 25 bedding plant cultivars were planted into $2.1-\mathrm{cm}$ diameter $\times 3.21-\mathrm{cm}$ deep plug flats filled with ProMix BX (Premier Horticulture, Quakertown, Pa., USA) on 27 Feb. and were grown in ambient lighting in a glass greenhouse maintained at $24{ }^{\circ} \mathrm{C}$ day and $18{ }^{\circ} \mathrm{C}$ night temperatures. Seedlings were transplanted into cell packs $(8 \times 8 \times 8.9 \mathrm{~cm})$ on 24 March. Plants were watered as needed and fertilized three times a week with Peters Soluble (10N-4.4P-8.2K) fertilizer (Scotts Co., Marysville, Ohio, USA). Plants were transplanted into trial beds at the Missouri State University Darr Agricultural Center in early May. Plants were placed either in ground beds or into $181.6-\mathrm{kg}$ bags of topsoil (Green Country Soil, Miami, Okla., USA) placed on top of the ground in the plots. Long $\mathrm{X}$-shaped cuts were made on the bottoms of the bags to drain excess water. The tops of the bags were slit and plants were evenly spaced across the bag surface, and were planted to the level of their root ball. There were 10 plants per treatment in the ground beds and three plants per bag of topsoil. Treatments were replicated three times using a completely randomized design. All plants were mulched after planting with about $7.5 \mathrm{~cm}$ of cypress bark. The cypress bark was used to cover the bags of soil completely so they would not be visible. Plants were fertilized after planting and again in July with Peters Soluble (20N-8.8P-16.4K) general-purpose fertilizer. Plants were irrigated by hand or sprinkler once a month until mid August and then every other week through mid September. No insecticides were used. Fluazifop-Pbutyl (fluazifop-P-butyl, Ornamec; PBI/Gordon, Kansas City, Mo., USA) was applied in early July for control of grassy weeds. Data on plant height and spread (width $\times$ width), as well as visual ratings of the appearance of each plant, were taken on 16 Sept. Data were analyzed using SPSS (v. 10.0) using independent $t$-tests. Significance is at the $5 \%$ level. marketed as alternatives to hanging baskets for ornamentals (Relf, 1989), and are available for growing tomatoes and other crops in greenhouses (Carpenter, 1981). Grow bags are successfully used in the production of transplantable woody nursery crops (Reiger, 1988). Consumer horticulturist Paula Relf reported that some garden centers and catalogs sell planting bags with slits that are suitable for most small vegetables and flow-

\section{3}

Seeds of 'Margarita Scarlet' rose moss, petunia, 'Amazon Neon Cherry' dianthus, and 'Mediterranean Punch' vinca were sown into $2.1-\mathrm{cm}$ diameter $\times 3.21-\mathrm{cm}$ deep plug flats filled with ProMix BX on 23 Feb., and were grown in ambient lighting in a glass 'Lavender Wave' petunia, 'Purple Wave' 
greenhouse maintained at $24{ }^{\circ} \mathrm{C}$ day and $18{ }^{\circ} \mathrm{C}$ night temperatures. Seedlings were transplanted into cell packs $(8 \times 8 \times 8.9 \mathrm{~cm})$ on 26 March. Plants were watered as needed and fertilized three times a week with Peters Soluble (20N-8.8P-16.4K) fertilizer. On 13 May, the plants were transplanted into ground beds or bags of topsoil placed on the ground. Long diagonal cuts were made in the bottom of each bag as they were placed on the ground surface. The tops of the bags were cut open and flaps were folded back against the sides. Treatments were replicated 10 times, with three plants per replication, for a total of 30 plants of each cultivar in bags and 30 plants in ground beds. All plants were mulched with about $7.5 \mathrm{~cm}$ of coarse sawdust. Growth and quality of the plants were determined by measuring plant spread, plant height, and flower number on 3 July, 29 July, and 5 Sept. Temperature of the soil in the bags was taken on the same dates at about $1400 \mathrm{HR}$. Three people assigned visual ratings to each plant on the last two dates, assigning a ranking of 1 to 5 for each treatment $(1=$ excellent, $2=$ good, $3=$ fair, $4=$ poor, $5=$ dead). Factors considered when ranking the plants included compact habit, branching habit, foliage color, and number of flowers. Data were analyzed using SPSS 10.0 using an independent $t$-test for comparing means between the two growing regimes.

\section{Results}

\section{2}

The response to the two planting methods varied by species and sometimes by cultivar within species (Table 1). Planting method had no effect on height, spread, or visual ratings of seven of the 25 cultivars tested: 'Purple Knight' alternanthera, 'Chilly Chili' ornamental pepper, 'Durango Red' marigold, 'Tidal Wave Silver' petunia, 'Wave Lavender' petunia, peek-a-boo plant, and 'Big Ruby' vinca. Planting method affected either height or spread, but not visual ratings, of seven cultivars. Two cultivars of dianthus were significantly shorter when grown in bags compared with dianthus grown in the ground, but spread and appearance were similar regardless of planting method. Five cultivars of petunias, which tend to sprawl, grew wider when planted in the ground than when planted in bags, but their height and appearance were unaffected by planting method. Those five cultivars were 'Blue Wave', 'Clear Waterfall Mix', 'Easy Wave Pink', 'Madness Magenta', and 'Stars and Stripes'. Planting method did not affect height of 'Orange Cream' gazania, but plants grown in bags were wider and had better visual ratings than the same cultivar grown in the ground. 'Tiger Mix' gazania was considered more attractive in bags than in the ground, but planting method did not affect height or spread. The opposite was true for 'Durango Bolero' marigold and 'Old Glory' petunia, which were considered more attractive in the ground than in bags, but height and spread were unaffected by planting method. Three cultivars were taller, wider, and more attractive in the ground than when grown in bags: 'Blue Ribbon' salvia, 'Quartz Waterfall Mix' verbena, and 'Icy Pacifica Pink' vinca. The bag planting method resulted in taller and more visually pleasing plants, but not wider growth, for 'Durango Tangerine' marigolds compared with the same cultivars planted in the ground. Conversely, the ground planting method resulted in taller and more visually pleasing plants, but not wider growth, for 'Bonanza Harmony' marigold and 'Durango Yellow' marigold. 'Liberty for All' verbena plants died when grown in the ground beds but survived when planted in the bags.

\section{3}

Planting method did not affect growth, flower number, or visual quality of 'Margarita Scarlet' rose moss except on the final evaluation date, when it was considered more attractive growing in the bags than in the ground (Table 2). Height and spread were greater for 'Lavender Wave' petunia grown in the ground than in bags on 3 July or 29 July, but height and spread were similar in both treatments on $5 \mathrm{Sept}$. The 'Lavender Wave' petunias had more flowers when grown in the ground than in bags on 3 July, but flower numbers were not different on 29 July or 5 Sept. Visual quality of 'Lavender Wave' was unaffected by treatment. Height of 'Purple Wave' petunias in the ground and in bags was similar on 3 July, but plants in the ground grew taller than plants in bags as the season continued. 'Purple Wave' plants were wider when grown in the ground than when grown in bags at all dates. Flower number was significantly greater on plants in the ground than plants in bags on 3 July and 5 Sept., but not on 29 July. The 'Purple Wave' petunias had similar visual quality ratings on 29 July regardless of treatment, but those grown in the ground were rated

Table 1. Height, spread, and visual ratings in mid Sept. 2002 of bedding plant species grown in bags and in the ground.

\begin{tabular}{|c|c|c|c|c|c|c|c|c|c|}
\hline \multirow[b]{2}{*}{ Species } & \multicolumn{3}{|c|}{ Height, cm } & \multicolumn{3}{|c|}{ Average spread, cm } & \multicolumn{3}{|c|}{ Visual rating ${ }^{z}$} \\
\hline & Ground & Bags & Sig. & Ground & Bags & Sig. & Ground & Bags & Sig \\
\hline Alternanthera dentate Purple Knight & $63.5^{y}$ & 40.1 & NS & 90.2 & 62.0 & NS & 1.4 & 2.0 & NS \\
\hline Capsicum annuum Chilly Chili & 21.8 & 22.6 & NS & 24.4 & 20.6 & NS & 1.2 & 1.3 & NS \\
\hline Dianthus Amazon Neon Cherry & 40.6 & 27.2 & $*$ & 32.5 & 31.5 & NS & 2.5 & 2.5 & NS \\
\hline Dianthus Corona Cherry Magic & 7.6 & 9.7 & $*$ & 29.7 & 18.3 & NS & 1.9 & 3.1 & NS \\
\hline Gazania rigens Orange Cream & 7.1 & 9.4 & NS & 9.1 & 17.8 & $*$ & 3.8 & 3.1 & $*$ \\
\hline Gazania rigens Tiger Mix & 5.8 & 9.7 & NS & 8.1 & 15.7 & NS & 3.9 & 2.4 & ** \\
\hline Tagetes patula Bonanza Harmony & 32.5 & 16.5 & $*$ & 57.2 & 38.9 & NS & 2.7 & 4.4 & ** \\
\hline Tagetes patula Durango Bolero & 33.8 & 26.9 & NS & 46.7 & 37.3 & NS & 1.5 & 2.0 & $*$ \\
\hline Tagetes patula Durango Red & 32.5 & 30.0 & NS & 36.8 & 35.3 & NS & 2.3 & 2.5 & NS \\
\hline Tagetes patula Durango Tangerine & 10.7 & 30.2 & $*$ & 26.2 & 25.1 & NS & 4.4 & 2.5 & ** \\
\hline Tagetes patula Durango Yellow & 34.8 & 27.7 & $*$ & 41.9 & 33.8 & NS & 2.0 & 2.6 & $*$ \\
\hline Petunia hybrida Blue Wave & 15.2 & 15.2 & NS & 45.2 & 22.1 & $*$ & 1.5 & 2.3 & NS \\
\hline Petunia hybrida Clear Waterfall Mix & 27.9 & 27.9 & NS & 36.1 & 24.6 & $*$ & 2.7 & 2.5 & NS \\
\hline Petunia hybrida Easy Wave Pink & 16.0 & 16.0 & NS & 45.2 & 28.4 & $*$ & 1.3 & 1.6 & NS \\
\hline Petunia hybrida Madness Magenta & 22.9 & 22.1 & NS & 40.6 & 21.3 & $* *$ & 2.5 & 2.3 & NS \\
\hline Petunia hybrida Old Glory & 9.4 & 26.7 & NS & 51.6 & 45.7 & NS & 1.5 & 2.8 & $*$ \\
\hline Petunia hybrida Stars and Stripes & 27.4 & 26.9 & NS & 43.7 & 24.1 & $*$ & 2.4 & 2.5 & NS \\
\hline Petunia hybrida Tidal Wave Silver & 38.9 & 42.4 & NS & 43.7 & 39.9 & NS & 1.5 & 1.0 & NS \\
\hline Petunia hybrida Wave Lavender & 17.0 & 15.2 & NS & 60.5 & 52.3 & NS & 1.3 & 1.3 & NS \\
\hline Salvia splendens Blue Ribbon & 40.4 & 29.7 & $* *$ & 39.4 & 26.2 & $* *$ & 1.8 & 2.3 & ** \\
\hline Spilanthes oleracea & 21.1 & 20.6 & NS & 30.2 & 31.5 & NS & 3.2 & 3.2 & NS \\
\hline Verbena Liberty for All & 0.0 & 8.4 & $* *$ & 0.0 & 13.5 & $* *$ & 5.0 & 3.7 & ** \\
\hline Verbena Quartz Waterfall Mix & 26.2 & 6.6 & $* *$ & 38.4 & 8.9 & $* *$ & 2.1 & 4 & $*$ \\
\hline Catharanthus roseus Big Ruby & 38.6 & 33.0 & NS & 31.8 & 32.5 & NS & 2.5 & 2.7 & NS \\
\hline Catharanthus roseus Icy Pacifica Pink & 33.3 & 19.6 & $* *$ & 33.3 & 22.4 & $*$ & 2.6 & 3.6 & \\
\hline
\end{tabular}

Mean separation within rows for each growth parameter.

${ }^{\mathrm{z}}$ Visual ratings were based on the following values: $1=$ excellent, $2=\operatorname{good}, 3=$ fair, $4=$ poor, $5=$ dead (average of three ratings).

${ }^{\mathrm{y}}$ Mean separation within rows by independent $t$-test for each growth parameter.

Ns, $*, * *$ Nonsignificant or significant at $P \leq 0.05$ or 0.01 , respectively. 
Table 2. Height, spread, flower number, and visual quality of plants grown in bags and in the ground in 2003.

\begin{tabular}{|c|c|c|c|c|c|c|c|c|c|c|c|c|}
\hline \multirow[b]{2}{*}{ Production system } & \multicolumn{3}{|c|}{ Height, cm } & \multicolumn{3}{|c|}{ Spread, cm } & \multicolumn{3}{|c|}{ No. of flowers } & \multicolumn{3}{|c|}{ Visual qualityz } \\
\hline & 3 July & 29 July & 5 Sept. & 3 July & 29 July & 5 Sept. & 3 July & 29 July & 5 Sept. & 3 July & 29 July & 5 Sept. \\
\hline \multicolumn{13}{|c|}{ Portulaca grandiflora 'Margarita Scarlet' } \\
\hline $\mathrm{Bag}$ & $11.2^{\mathrm{y}}$ & 13.0 & 12.4 & 22.4 & 24.4 & 24.4 & 2.4 & 5.6 & 6.3 & - & 2.6 & 3.5 \\
\hline Ground & 10.2 & 19.6 & 13.7 & 20.6 & 28.2 & 25.4 & 1.5 & 7.7 & 8.9 & - & 2.2 & 3.9 \\
\hline$P$ value & NS & NS & NS & NS & NS & NS & NS & NS & NS & & NS & $*$ \\
\hline \multicolumn{13}{|c|}{ Petunia hybrida 'Lavender Wave' } \\
\hline Bag & 10.9 & 15.5 & 20.3 & 25.4 & 41.9 & 56.6 & 6.4 & 1.0 & 88.5 & - & 2.3 & 1.1 \\
\hline Ground & 14.7 & 21.3 & 19.3 & 41.7 & 68.1 & 65.5 & 19.3 & 0.9 & 83.2 & - & 2.1 & 1.2 \\
\hline$P$ value & $* * *$ & $* * *$ & NS & $* * *$ & $* * *$ & NS & $* * *$ & NS & NS & & NS & NS \\
\hline \multicolumn{13}{|c|}{ Petunia hybrida 'Purple Wave' } \\
\hline Bag & 9.7 & 11.7 & 12.7 & 27.2 & 16.5 & 40.1 & 5.7 & 5.8 & 39.3 & - & 1.0 & 3.0 \\
\hline Ground & 10.2 & 15.2 & 20.1 & 41.4 & 22.1 & 67.1 & 21.8 & 1.1 & 95.6 & - & 0.9 & 1.9 \\
\hline$P$ value & NS & $*$ & $* *$ & $* * *$ & $* * *$ & $* * *$ & $* * *$ & NS & $* * *$ & & NS & $* *$ \\
\hline \multicolumn{13}{|c|}{ Dianthus barbatus 'Amazon Neon Cherry' } \\
\hline Bag & 7.4 & 10.2 & 10.9 & 9.7 & 12.4 & 14.2 & 2.3 & 4.3 & 2.8 & - & 2.8 & 3.4 \\
\hline Ground & 10.7 & 13.5 & 15.0 & 12.2 & 17.5 & 20.6 & 4.3 & 15.0 & 9.0 & - & 2.7 & 2.9 \\
\hline$P$ value & $* * *$ & $* *$ & $* *$ & $* *$ & $* * *$ & $* *$ & $* *$ & $* * *$ & $* * *$ & & NS & $*$ \\
\hline \multicolumn{13}{|c|}{ Catharanthus roseus 'Mediterranean Punch' } \\
\hline Bag & 8.1 & 9.7 & - & 8.4 & 10.2 & - & 0.7 & 10.0 & - & - & 1.7 & - \\
\hline Ground & 7.6 & 7.6 & - & 7.9 & 20.6 & - & 0.5 & 5.0 & - & - & 1.6 & - \\
\hline$P$ value & NS & NS & & NS & NS & & NS & NS & & & NS & \\
\hline
\end{tabular}

${ }^{\mathrm{z}}$ Visual ratings were based on the following values: $1=$ excellent, $2=$ good, $3=$ fair, $4=$ poor, $5=$ dead (average of three ratings)

${ }^{y}$ Mean separation within rows by independent $t$-test for each growth parameter.

Ns,*,**,***Nonsignificant or significant at $P \leq 0.05,0.01$, or 0.001 , respectively.

higher than those in bags on 5 Sept. 'Amazon Neon Cherry' dianthus performed better throughout the season when grown in the ground than in bags, with greater height and spread and larger numbers of flowers. Visual quality of the ground-grown plants was rated higher only on 5 Sept., but not on 29 July. Planting method did not affect growth or performance of 'Mediterranean Punch' vinca. These plants developed crown rot and all died by the third evaluation date. Root temperature was significantly higher in the bag soil than the ground at all three dates (Table 3).

\section{Discussion}

Growth responses to the two planting methods varied by species and sometimes by cultivar within species. Studies comparing bag production and traditional production in greenhouse conditions have shown higher yields for plants in bags. In unheated greenhouse conditions, strawberries (Fragraria L.) grown in bags had higher early yields and higher overall yields than strawberries grown in raised beds, although planting method did not affect average fruit weight (Özdemir and Gündüz, 2004). Researchers saw an increase in the number of stems when carnations were grown in hydroponic bags covered by a plastic film tunnel compared with plants grown on flat soil (Marfá et al., 1989). The "Gardening in a Bag" system could be compared

Table 3. Soil temperature in bags and in the ground in 2003.

\begin{tabular}{lccc}
\hline & \multicolumn{3}{c}{ Soil Temperature, ${ }^{\circ} \mathrm{C}$} \\
\cline { 2 - 4 } & 3 July 2003 & 29 July 2003 & 5 Sept. 2003 \\
\hline Bag & 26.3 & 28.1 & 27.6 \\
Ground & 24.8 & 26.1 & 24.0 \\
$P$ value & $*$ & $*$ & $*$ \\
\hline
\end{tabular}

* Significant at $P \leq 0.01$. with growth of plants in raised beds. In raised bed production versus ground production, growth responses have also been species specific. Peach (Prunus persica L. Batsch “ Redhaven/Siberian C.') trees had greater trunk diameter and higher yield when grown in raised beds compared with peach trees grown in ground beds (Funt et al., 1997). Slash pines (Pinus elliottii Engelm. var. elliottii) grew taller in raised beds than in ground beds (Wilhite and Jones, 1981), and sorghum (Sorghum bicolor L. Moench) yield was higher when the crop was grown on raised beds than when grown on conventional flat seedbeds (Mascagni et al., 1991). Yield increases were also seen in cereal, pulse, and oilseed crops grown in raised beds versus crops grown on the wet, poorly productive land in Western Australia (South Perth, W.A. Dept. Agr. 1999/2000). In contrast, raised beds had no effect on yield of pepper (Capsicum annuum L. 'Skipper') unless the raised beds were also mulched (Call and Courter, 1989) or on carrots (Daucus carota var. sativus, 'Spartan Fancy') on peat bogs in Canada, although the carrots grown in raised beds were longer than carrots grown in the ground (LeBlanc and Thebeau, 1995).

Bedding plants in this study varied in height, weight, and appearance rating. Some of the bedding plant species in our study were taller, wider, and nicer looking when grown in the ground compared with those grown in bags. These plants may have had greater access to water and nutrient resources than the plants with root systems confined to the bags. Water availability plays a larger role than any other factor in controlling the distribution of vegetation on the earth's surface (Kramer, 1969). Root substrate temperature also may have affected growth of the plants. Root substrate temperatures were slightly lower in the soil than in the bags throughout the growing season - a factor that would favor plants preferring cooler growing conditions. Species that prefer cooler growing environments, such as dianthus, tended to do better planted in soil than bags. Researchers have suggested that root zone temperature affects growth of watermelon (Citrullus lanatus Thunb.; Andino and Motsenbocker, 2004), pepper (Capsicum annuum L.; Dodd et al., 2000), and tomato (Lycopersicon esculentum P. Mill.; Diaz-Perez and Batal, 2002), and that there is an optimum root zone temperature for each species (Diaz-Perez and Batal, 2002; Diaz-Perez et al., 2004).

'Purple Knight' alternanthera, 'Chilly Chili' ornamental pepper, 'Durango Red' marigold, 'Tidal Wave Silver' petunia, 'Wave Lavender' petunia, peek-a-boo plant, and 'Big Ruby' vinca were unaffected by differences in planting method. These species are native to subtropical or tropical regions and may not have been affected by the warmer bag temperatures. Although we did not analyze root growth of plants, the species growing in bags may have produced root systems that grew into the underlying soil.

Throughout the experiment, the petunias were wider when planted in the ground than when planted in bags.

In 2002, our research plots suffered some flooding damage in July. Verbena growing in bags survived whereas verbena in soil died of a root rot disease. Waterlogged soil impairs the performance of roots and allows rootrotting fungi to attack plant root systems more easily (Becker, 1990). Bags are essentially raised beds, which drain quicker than soil at ground level (Becker, 1990; Elliott, 1979; Gray, 1991; Relf, 1989). Raised bed production has also been shown to help control root diseases in raspberries (Heiberg, 1999; Maloney et al., 1993) and azaleas (Benson and Jones, 1979), and to improve 
relations between plant roots and beneficial mycorrhizae (Sylvia et al., 1998).

Even though height or spread of plants grown in the ground was often different from height or spread of plants in bags, the difference was not always visually apparent. In many instances, visual appearance ratings were high on plants in bags even though the plants were smaller than the same species grown in the ground. Compact plants may be preferred in cases when gardening space is limited, to avoid overcrowding of plants, or to provide the appearance of dense flowering. Because visual quality was generally unaffected by growth in the bag versus the soil, the labor-saving benefits of growing bedding plants in a bag may make it a useful means for bedding plant displays in landscapes where soil quality is poor or people lack time to prepare the soil. "Gardening in a Bag" is a promising method for growing annual bedding plants, especially for gardeners wanting to contain plant growth of ornamentals to a small space.

\section{Literature Cited}

Adams, P. 1990. Effects of watering on the yield, quality and composition of tomatoes grown in bags of peat. J. Hort. Sci. 65:667-674.

Andino, J.R. and C.E. Motsenbocker. 2004. Colored plastic mulches influence cucumber beetle populations, vine growth, and yield of watermelon. HortScience 39:1246-1249.

Becker, R. 1990. Raised beds promote vigorous seedlings. Ag Impact. 17:9-10.

Benson, D. and R. Jones. 1979. Planting in raised beds reduces severity of Phytophthora root rot of azalea. Proc. Southern Nurserymen's Assn. Res. Conf., Annu. Rpt. 24:123-124. Southern Nurseryman's Assn., Nashville, Tenn.

Call, R. and J. Courter. 1989. Response of bell pepper to raised beds, black plastic mulch, spunbonded row cover and trickle irrigation. Proc. Natl. Agr. Plastics Congr. 21:140-148.

Carpenter, T.D. 1981. Growing vegetables in upright polyethylene bags. Proc. Natl. Agr. Plastics Congr. 16:14-21.

Diaz-Perez, J.C. and K.D. Batal. 2002. Colored plastic film mulches affect tomato growth and yield via changes in root-zone temperature. J. Amer. Soc. Hort. Sci. 127:127-136.

Diaz-Perez, J.C., D. Granberry, D. Bertrand, and D. Giddings. 2004. Tomato plant growth during establishment as affected by root zone temperature under colored mulches. Acta Hort. 631:119-124.

Dodd, I.C., J. He, C.G.N. Turnbull, S.K. Lee, and C. Critchley. 2000. The influence of supraoptimal root-zone temperatures on growth and stomatal conductance in Capsicum annuum L.J. Exp. Bot. 51:239-248.

Elliott, J. 1979. Raised beds and gravel. The Garden. 104:237-240.

Finnis, V. 1973. Raised beds for rock plants. J.R. Hort. Soc. 96:249-254.

Funt, R.C., M.C. Schmittgen, and G.O. Schwab. 1997. Raised beds and microirrigation influence peach production. HortScience 32:677-682.

Gray, S. 1991. Raised bed gardening. OSU extension facts. Coop. Ext. Serv. Okla. State Univ. Div. of Agr.

Heiberg, N. 1999. Effects of raised beds, black soil mulch and oxadixyl on root rot (Phytophthora fragariae var. rubi) in red raspberry. Acta Hort. 505:249-255.

Hochmuth, R., L.L. Leon, T. Crocker, D. Dinkins, and G. Hochmuth. 1998. Evaluation of two soilless growing media and three fertilizer programs in outdoor bag culture for strawberry in North Florida. Proc. Fla. State Hort. Soc. 111:341-344.

Keever, G.J., G.S. Cobb, and R.B. Reed. 1985. Effects of container dimension and volume on growth of three woody ornamentals. HortScience 20:276-278.

Kramer, P.J. 1969. Plant and soil water relationships: A modern synthesis. McGraw-Hill, New York.

LeBlanc, P. and G. Thebeau. 1995. Effect of raised beds on yield and quality of carrots grown in organic soil. J. Veg. Crop Prod. 1:3-10.

Maloney, K.E., W.F. Wilcox, and J.C. Sanford. 1993. Raised beds and metalaxyl for controlling phytophthora root rot of raspberry. HortScience 28:1106-1108.

Malorgio, F., F. Lemmetti, F. Tognoni, and C.A Campiotti. 1994. The effect of substrate and watering regime on chrysanthemum grown with soilless culture. Acta Hort. 361:495507.

Marfá, O., R. Savé, L. Serrano, and E. Roselló. 1989. Carnation bag cultures on steep gradient soil. Acta Hort. 246:37-44.
Mascagni, H.J. Jr., T.C. Keisling, and W.E. Sabbe. 1991. Nitrogen efficiency of grain sorghum grown on flat and raised seedbeds on poorly drained soil. J. Plant Nutr. 14:1119-1131.

Mattas, K., M. Bentes, G. Paroussi, and I. Tzouramani. 1997. Assessing the economic efficiency of a soilless culture system for offseason strawberry production. HortScience $32: 1126-1129$

Mavrogiannopoulos, G.N., and J.G. Papadakis. 1987. The effect of bag size on tomatoes in bags with perlite. Soilless Cult. 3:71-76.

Menzel, D.M., D.W. Turner, V.J. Doogan, and D.R. Simpson. 1994. Root shoot interactions in passionfruit (Passiflora sp.) under the influence of changing root volumes and soil temperatures. J. Hort. Sci. 69:553-564.

Özdemir, E., and K. Gündüz. 2004. Comparison of bag and raised bed treatments for strawberry production under unheated greenhouse conditions. J. Amer. Pomol. Soc. 58:118-122.

Pinnell, M.M. 1990. The container culture. Amer. Nurseryman. 172:47-48, 50-51.

Purser, J. and M. Comeau. 1991. The effects of raised beds, plastic mulches and row covers on soil temperature. Proc. Natl. Agr. Plastics Congr. 23:220-222.

Reiger, K. 1988. The bag way: Root-control bags are a feasible alternative to the $\mathrm{B} \& \mathrm{~B}$ method of growing and transplanting trees and shrubs. Amer. Nurseryman. 168:117-119.

Reiger, R. and C.E. Whitcomb. 1983. A root control system for growing and transplanting trees. Okla. Agr. Expt. Sta. Res. Rpt. 843:11-17.

Relf, P.D. 1989. Gardening in raised beds and containers for elderly and physically handicapped. Virg. Coop. Ext. Serv. Article 426-020, Virg. Polytechnic Inst. and State Univ. Ext. Div., Blacksburg, Va.

Sheldrake, R. 1983. Bag culture update. Amer. Veg. Grower. 31:32-33.

South Perth, W.A. Dept. Agr. 1999/2000. Raised beds prevent waterlogging and increase productivity. J. Agr. 41:3-9.

Sylvia, D., A. Alagely, D. Kent, and R. Mecklenburg. 1998. Mycorrhizae of landscape trees produced in raised beds and containers. J. Arboricult. 24:308-315.

Walters, P. 1998. Growing in raised beds. AgVentures. Schatz Pub. Group. Blackwell, Okla.

Wilhite, L.P. and E.P. Jones. 1981. Bedding effects in maturing slash pine stands. Southern J. Appl. For. 5:24-27. 